\title{
O STANOWIENIU TEORII ŚREDNIEGO ZASIĘGU W NAUKACH SPOEECZNYCH ROZWAŻANIA NA PRZYKŁADZIE NAUKI RACHUNKOWOŚCI
}

\section{WSTĘP}

Kwestia sposobu prowadzenia badań, doboru stosowanych metod naukowych oraz metod i procedur badawczych czy rodzaju teoretyzowania i typu generowanej teorii jest dla każdego naukowca kwestią niezwykłej wagi. Istotny w tym kontekście jest fakt, że takie dyscypliny nauki, jak ekonomia czy finanse, a tym samym rachunkowość, stają się coraz bardziej społeczne, behawioralne. Takie zmiany zachodzace $\mathrm{w}$ samej nauce i siłą rzeczy w generowanych przez nią teoriach wymagają szerszego spojrzenia na to, co dobre i sprawdzone w innych naukach społecznych zajmujących się stricte zachowaniem człowieka. Celem artykułu jest przybliżenie pojęcia „teoria średniego zasięgu" oraz zabranie głosu w dyskusji nad zasadnościa generowania takiego typu teorii w szeroko rozumianych naukach społecznych ${ }^{1}$. Rozważania zilustrowane zostaną przykładem z nauki rachunkowości.

\section{POJĘCIE TEORII}

Rozważania na temat teorii średniego zasięgu należy rozpoczać od przybliżenia samego pojęcia „teoria”. Zgodnie z słownikowymi i encyklopedycznymi definicjami - internetowym wydaniem Stownika języka polskiego PWN - teoria to „całościowa koncepcja zawierajacca opis i wyjaśnienie określonych zjawisk i zagadnień” oraz „czyjakolwiek koncepcja na określony temat” Zgodnie ze Słownikiem wyrazów obcych $i$ zwrotów obcojęzycznych Włady-

${ }^{1}$ Mowa tu o obszarze wiedzy, a nie tylko o samej dziedzinie nauki. Dotychczas bowiem, jak wskazuje się w literaturze, teorie średniego zasięgu były przedmiotem rozważań metodologicznych przede wszystkim z zakresu dziedziny nauk społecznych, a ściślej: takich dyscyplin, jak socjologia czy psychologia. Jednak wspomniane zmiany powoduja, że należy zastanowić się nad adekwatnością tego typu teorii także dla nauk społecznych rozumianych jako obszar wiedzy, w którym zawiera się dziedzina nauk ekonomicznych, w skład której wchodzą takie dyscypliny naukowe, jak ekonomia czy finanse, w tym nauka rachunkowości.

${ }^{2}$ Zob. www.sjp.pwn.pl. 
sława Kopalińskiego pojęcie „teoria w nauce” należy rozumieć jako „zbiór praw, definicji i hipotez rzeczowo i logicznie powiązanych w całość; wiedzę tłumaczącą jakąś dziedzinę zjawisk, w odróżnieniu od praktyki, z którą jednak pozostaje w związku"3, a z kolei według encyklopedii PWN - teoria naukowa jest systemem twierdzeń logicznie i rzeczowo uporządkowanych, powiązanych określonymi stosunkami logicznymi, występującymi $\mathrm{w}$ danej nauce oraz spełniającymi przyjęte w niej kryteria naukowości i poprawności metodologicznej ${ }^{4}$.

Już samo powyższe krótkie zestawienie ujęcia słownikowo-encyklopedycznego wskazuje, że nie ma jednej interpretacji tego terminu. Nie inaczej jest w literaturze. Prowadzi to do tego, że - jak to celnie zauważa Robert K. Merton - „słowu »teoria« jak tylu innym używanym nazbyt często grozi utrata znaczenia. Jego odniesienia są tak zróżnicowane - obejmują wszystko od skromnych hipotez roboczych, przez czytelne, ale niesprecyzowane i nieuporządkowane spekulacje myślowe, aż po systemy aksjomatyczne - że słowo to często raczej zaciemnia obraz zamiast ułatwiać zrozumienie sensu"

Bez wgłębiania się dalej w zawiłości definicyjne, zdaniem autorki, w literaturze najczęściej definiuje się teorię w trzech znaczeniach (na trzech poziomach):

- pierwszym, w którym, jak twierdzi Krzysztof G. Szymański, termin „teoria” w badaniach naukowych rozumiany jest „w sensie zbioru powiazanych ze sobą twierdzeń, opisujących określoną dziedzinę przedmiotowa. Twierdzenia te mogą być mniej lub bardziej ściśle powiązane"6;

- drugim, w którym następuje łączenie pojęcia „teoria” z pojęciem „twierdzenia” i zgodnie z którym „termin »teoria« może być stosowany na oznaczenie poszczególnych twierdzeń, mających istotne znaczenie z punktu widzenia wiedzy naukowej w danej dziedzinie";

- trzecim, w którym wskazuje się, że wielokrotnie termin „teoria” jest używany także nawet „w odniesieniu do zbioru nie sprawdzonych empirycznie sądów, zbioru hipotez, "mniemań«, poglądów dotyczących pewnego problemu”"

\section{PRAGENEZA POWSTANIA TEORII ŚREDNIEGO ZASIĘGU - ODRZUCENIE ZALOŻENIA O METODOLOGICZNEJ JEDNOŚCI NAUKI}

Zdaniem autorki, korzeni powstania idei generowania teorii średniego zasięgu należy szukać w fakcie dojścia do konstatacji, że rozważenia wymaga zasadność tezy o metodologicznej jedności nauki, zwanej monizmem naukowym (doktryną jedności metody naukowej) czy też naturalizmem. Samo pojęcie monizmu, jak wynika z opisu zawartego w Stowniku wyrazów obcych

\footnotetext{
${ }^{3}$ Zob. http://www.slownik-online.pl/kopalinski/F82C160ACEF5A946C12565850075E582.php.

${ }^{4}$ Nowa encyklopedia powszechna PWN, t. 6, Warszawa 1997, s. 361.

${ }^{5}$ R. K. Merton, Teoria socjologiczna i struktura spoteczna, Warszawa 2002, s. 61.

${ }^{6}$ K. G. Szymański, Problemy metodologiczne nauki rachunkowości, Warszawa 1988, s. 28.

${ }^{7}$ Ibidem, s. 29.
} 
$i$ zwrotów obcojęzycznych Kopalińskiego, oznacza „jednorodność metodologicznąnauk przyrodniczych i społecznych"s (wyróż. - A.P.-K.).

Przytoczone pojęcie „naturalizm” wprowadzone zostało przez Karla Poppera w The Poverty of Historicism, gdzie przeciwstawił je antynaturalizmowi metodologii nauk społecznych. Istotę tego przeciwstawienia celnie wyjaśnia Edmund Mokrzycki, który pisze, że zdaniem Karla Poppera w metodologii nauk społecznych istnieja dwa podejścia: „pronaturalistyczne” albo „pozytywne", w których opowiada się za stosowaniem metod fizyki (nauk przyrodniczych) w naukach społecznych, oraz „,antynaturalistyczne” lub „negatywne”, jeśli oponuje przeciw stosowaniu tych metod ${ }^{9}$.

W drugiej połowie XX czy w XXI w. podejście polegające na odrzuceniu monizmu nie jest już niczym nadzwyczajnym. Przykładowo w latach osiemdziesiątych XX w. Mokrzycki pisał: „sądzę, że refleksja nad metodologicznymi podstawami nauk społecznych musi się uniezależnić od refleksji nad metodologicznymi podstawami nauk przyrodniczych. Uniezależnić nie w tym sensie, by nie dopuszczać wymiany myśli, lecz w tym sensie, by poszukiwania prowadzić na własną rękę, metodą analizy własnej sfery rzeczywistości kulturowej, tj. nauk społecznych, a nie za pomoca takiego czy innego metodologicznego modelu nauk przyrodniczych" ${ }^{10}$. Przykładem prezentacji takich poglądów sa pochodzące $\mathrm{z}$ lat dziewięćdziesiątych XX w. publikacje Ludwiga von Missesa czy Jerzego Apanowicza ${ }^{11}$. Wcześniej jednak (przed publikacja The Poverty of Historicism) formułowanie takich sądów było raczej rzadkością ${ }^{12}$, ponieważ przed usankcjonowaniem możliwości negowania zasadności monizmu jedynym słusznym poglądem było uznawanie starych założeń powstałych jeszcze w czasach koła wiedeńskiego, czyli w latach trzydziestych XX w. Przedstawiciele tego nurtu formułowali sądy o konieczności stosowania monizmu naukowego i „traktowania fizyki jako dyscypliny najbardziej rozwiniętej i wzorcowej”"13. W'śód nich aktywni byli choćby Otto Neurath ${ }^{14}$ i Herbert Feigl ${ }^{15}$, których to poglądy Mokrzycki nazywa nawet nie realizacją koncepcji monizmu naukowego, ale radykalnym fizykalizme m ${ }^{16}$.

${ }^{8}$ Zob. http://www.slownik-online.pl/kopalinski/F82C160ACEF5A946C12565850075E582.php.

${ }^{9}$ K. R. Popper, The Poverty of Historicism, New York 1960, s. 2; E. Mokrzycki, Metodologiczny dogmat naturalizmu, „Studia Filozoficzne” 1975, nr 7.

${ }^{10}$ E. Mokrzycki, Filozofia nauki a socjologia, Warszawa 1980, s. 19.

${ }_{11}$ Por. L. von Misses, Ludzkie działanie: traktat o ekonomii, „Prakseologia” 1995, nr 3-4, s. 41; J. Apanowicz, Metodologiczne uwarunkowania pracy naukowej, Prace doktorskie, prace habilitacyjne, Warszawa 2005, s. 23.

${ }_{12}$ Por. C. Hempel, The Logical Analysis of Psychology, w: H. Feigl, W. Sellars (red.), Readings in Philosophical Analysis, Appleton-Century-Crofts, New York 1949, s. 373-374.

${ }^{13}$ E. Mokrzycki, Filozofia nauki..., s. 92.

${ }_{14}$ Tłumaczenie oryginału z roku 1931: O. Neurath, Empiricism and Sociology. The Scientific Content of History and Political Economy, Dordrecht 1973, s. 360.

${ }^{15} \mathrm{H}$. Feigl, Unity of Science and Unitary Science, w: H. Feigl, Brodbeck (red.), Reading in the Philosophy of Science, New York 1953, s. 384. Piszą o tym K. Ajdukiewicz oraz C. F. von Weizsaecker. K. Ajdukiewicz w znanej publikacji (Język i poznanie. Wybór pism z lat 1945-1963, Warszawa 2006, s. 25), wskazuje Neuratha (oraz Carnapa) jako głównych rzeczników fizykalizmu. C. F. von Weizsaecker, Jedność przyrody, Warszawa 1978, s. 126-127.

${ }^{16}$ E. Mokrzycki, Filozofia nauki..., s. 117, 104 i 135. 
Jak wskazuje Mokrzycki, naukowcy zajmujący się naukami społecznymi stali w cieniu fizyki i karnie przyznawali, widząc, że nauki społeczne nie mogą wypracować takich teorii, jakie wypracowała fizyka, że ich nauka jest wobec niej i innych nauk przyrodniczych zapóźniona ${ }^{17}$. Co gorsza, czynili to tak naprawdę z obawy, że jeśli nie stwierdza, iż są w porównaniu z fizyką „naukowo upośledzeni”, to zostaną oskarżeni o to, że to, czym się zajmuja, w ogóle nie jest nauką. Nie było bowiem w tamtych czasach możliwości (odpowiednio przygotowanego gruntu), aby móc przyznać, że nauki społeczne sa innym rodzajem nauki i ${ }^{18}$ niż przyrodoznawstwo i nie są zapóźnione, lecz in ne, dlatego nie ma sensu generowanej przez nie teorii porównywać z kryteriami oceniajacymi teorię nauki takiej jak fizyka ${ }^{19}$.

\section{TEORIA ŚREDNIEGO ZASIĘGU A CAŁOŚCIOWE SYSTEMY TEORETYCZNE}

Aspektem różnic między teoriami stanowionymi w naukach społecznych a tymi, które powstają w przyrodoznawstwie, zajął się kompleksowo także Merton. Stwierdził on, że przekonanie naukowców zajmujących się naukami społecznymi, że „musimy mieć i to natychmiast wielki system teoretyczny”, jest mylne i „wypływa nie tylko z błędnego porównania (nauk społecznych, w tym socjologii) z naukami fizycznymi, lecz także wynika z błędnego założenia, iż nauka musi sprostać wszelkim stawianym jej wymaganiom - i głupim, i mądrym”, a przeświadczenie to jest oparte ,jedynie na implicite przyjętym świętokradczym i masochistycznym założeniu, że trzeba być wszechwiedzącym i wszechmogącym" ${ }^{20}$. Dlatego też próbę brnięcia naukowców zajmujących się naukami społecznymi w całościowy system teoretyczny, który mógłby zagwarantować, że w każdym danym momencie będzie można rozwiązać całą gamę problemów, jakie ludzie napotkaja, Merton określa jako „bezsensowny

${ }^{17}$ Takie podejście widać choćby w publikacjach Machlupa (F. Machlup, Are the Social Sciences Really Inferior?, w: M. Natanson [red.], Philosophy of the Social Sciences, New York 1963), czy Collinsa (R. Collins, 1996, Stownik angielsko-polski, red. J. Fisiak, Warszawa 1975).

${ }_{18}$ To, że nauki społeczne różnią się od nauk przyrodniczych, jest przedmiotem dyskusji zawartej w wielu opracowaniach. Jeszcze przed nastaniem lat sześćdziesiątych XX w. Johan Galtung daje przemyślaną listę dziesięciu rodzajów różnic pomiędzy naukami przyrodniczymi i społecznymi, a w roku 1985 (wyd. polskie - 1995), kompleksowo zajął się tą kwestią także Detel (w: E. Martens, H. Schnaedelbach, Filozofia, Wiedza Powszechna, Warszawa 1995, s. 233234). W Polsce kwestiami takimi zajmowali się przede wszystkim Ossowski oraz Sztompka, por. P. Sztompka, O osobliwościach nauk spotecznych raz jeszcze, „Studia Filozoficzne” 1974, nr 8(105), s. 13-16, oraz S. Ossowski, O osobliwościach nauk spotecznych, Warszawa 2001, s. 146159, do których, ze względu na ograniczony zakres niniejszego opracowania, autorka odsyła zainteresowanych, informując jednocześnie, że kwestia ta omówiona została także w: A. Piechocka-Kałużna, Wykorzystanie metody teorii ugruntowanej $w$ nauce rachunkowości na przyktadzie badań nad prawda w sprawozdawczości finansowej, Wyd. UEP, Poznań 2014.

${ }^{19}$ E. Mokrzycki, Filozofia nauki..., s. 124-125.

${ }^{20}$ R. K. Merton, op. cit., s. 70. 
masochizm badaczy społecznych” wzmacniany przez „mimowolny sadyzm opinii publicznej" 21 .

Powraca w tym miejscu pytanie: Dlaczego więc próbowano budować w naukach społecznych całościowe systemy teoretyczne? Czy jedyna przyczyna był wspomniany wynikający z monizmu naukowego kult fizykalizmu? Kwestię tę tłumaczy na przykładzie socjologii niezastapiony Merton. Pisze on następująco: „[...] musimy pamiętać, że wczesna socjologia wyrastała w atmosferze intelektualnej, w której ze wszystkich stron pojawiały się systemy filozoficzne o bardzo szerokim zasięgu. Każdy osiemnastowieczny i z początku dziewiętnastego wieku filozof z prawdziwego zdarzenia musiał zbudować swój system filozoficzny: weźmy tylko najbardziej znanych - Kanta, Fichtego, Schellinga, Hegla. Każdy system był osobistą zapowiedzią ostatecznego uporządkowania uniwersum materii, natury i człowieka" ${ }^{22}$. Takie właśnie wzorce w postaci „czynionych przez filozofów prób stworzenia systemów całościowych stały się wzorem dla wczesnych socjologów i dlatego dziewiętnasty wiek był wiekiem systemów socjologicznych", które były postrzegane jako rozłączne i w dużej mierze sprzeczne ${ }^{23}$.

$\mathrm{Na}$ marginesie należy obiektywnie zauważyć, że jak każda nowa, odważna koncepcja, tak i pomysł na konstruowanie przeciwieństwa całościowych teorii, minowicie tzw. teorii średniego zasięgu, znalazł swoich przeciwników. Pisano nawet, że jego zwolennicy cechują się ,,anemiczną ambicją, ,nie potrafią marzyć” i nie mają wizji, które zachęcały kiedyś ludzi „do wstapienia w świat nauki” ${ }^{24}$.

Cóż zatem wynika z powyższych rozważań? Otóż należy wskazać, że nauki społeczne zdecydowanie różnią się od nauk przyrodniczych, co przekłada się na fakt, że w ich przypadku trudne jest konstruowanie rewolucyjnych, ogólnych, „wszechogarniajaccych” i „wszechwyjaśniajacych” teorii, jakie znamy, choćby z systemów filozoficznych o bardzo szerokim zasięgu. W przypadku nauk społecznych konieczne jest - zdaniem Mertona - prowadzenie dociekań zwieńczonych teoriami średniego zasięgu wymagającymi całkiem innego rodzaju pracy niż te, które prowadzą do wszechobejmującej teorii ${ }^{25}$.

\section{PIERWSZE WZMIANKI NA TEMAT TEORII ŚREDNIEGO ZASIĘGU}

Pierwsze wzmianki, świadczące o pojawianiu się symptomów tego typu teoretyzowania, są widoczne już u samego Platona, który w swoim Teajtecie zauważa, że to „szczegóły są niezliczone, a wyższe uogólnienia nie wskazuja wystarczającego kierunku", co oznacza, zdaniem B a con a, który o tym pisze, że „istota rzeczy we wszystkich naukach, która powoduje, że uczony różni się

\footnotetext{
21 Ibidem, s. 70

22 Ibidem, s. 67

${ }^{23}$ Ibidem, s. 68.

${ }^{24}$ R. Bierstedt, Sociology and Humane Learning, „American Sociological Review” 25, 1960,

25 R. K. Merton, op. cit., s. 68.
} s. 6 . 
od laika, leży w pośrednich twierdzeniach biorących się w każdej nauce z tradycji i doświadczenia" ${ }^{26}$.

Wspomniany Bacon, oprócz powoływania się na Platona, jak z kolei pisze Mill27: „W większym stopniu niż ktokolwiek przed nim” podkreślał pierwszorzędne znaczenie „twierdzeń średniej ogólności” w nauce. Zapatrzenie Bacona na „zasady pośrednie” kosztem „najbardziej ogólnych praw” zauważał wcześniej również Le wi i ${ }^{28}$, o czym wspomina Merton ${ }^{29}$, dodajac od siebie, że Bacon pisał dobitnie, że „nie należy [...] pozwolić na to, ażeby rozum od szczegółów od razu przeskakiwał i niejako wzlatywał do oddalonych i jakby najogólniejszych twierdzeń (jakimi są tak zwane zasady naczelne umiejętności i rzeczy), i według ich rzekomo niewzruszonej prawdziwości uzasadniał i wprowadzał twierdzenia średniej ogólności”. Bacon ują to bardzo przejrzyście, otóż według niego „dla nauk wtedy dopiero będzie można rokować dobre nadzieje, kiedy po właściwej drabinie i po kolejnych szczeblach bez przerw i przeskoków wstępować się będzie od szczegółów do twierdzeń niższego rzędu, od tych do twierdzeń średniej ogólności; następnie do coraz wyższych i na końcu do najogólniejszych"30.

Przytoczone próby usankcjonowania teorii „średniej ogólności” nie znalazły jednak wtedy oddźwięku w naukach społecznych, a to z tego prostego powodu, że te ostatnie były dopiero na etapie wyodrębniania się z innych nauk. Dlatego ważniejszym przykładem zapisków, po wspomnianych pierwszych próbach popularyzowania teorii średniego zasięgu (choć jeszcze nie nazywanych w ten sposób), były te, które pojawiły się dopiero w latach trzydziestych XX w. Chodzi tu, w szczególności o dość istotne, choć zapomniane prace Karla Mannheima, Adolfa Loewego i Morrisa Ginsberga ${ }^{31}$. Prace te, choć przedwczesne, były o tyle istotne, że stały się bezpośrednią inspiracją dla publikacji Mertona, która dzięki temu, że w tym czasie nastapił znaczący rozwój nauk społecznych, trafiła wreszcie na podatny grunt.

\section{ROZKWIT TEORII ŚREDNIEGO ZASIĘGU - ZNACZENIE PUBLIKACJI MERTONA}

Nie dyskredytując opisanych w poprzednim punkcie podwalin pod teoretyzowanie średniego zasięgu, należy przyznać, że to jednak dopiero praca Mertona jest tak naprawdę pierwszą kompleksową publikacją traktującą o teoretyzowaniu takiego typu.

${ }^{26}$ F. Bacon, The Advancement of Learning, w: idem, Works, t. 2, red. B. Montague, London 1825, s. 177 ; R. K. Merton, op. cit., s. 78.

${ }_{27}$ J. S. Mill, System logiki dedukcyjnej i indukcyjnej, t. 2, Warszawa 1962, s. 666-667.

${ }^{28}$ G. C. Lewis, A Treatise on the Methods of Observation and Reasoning in Politics, t. 2, London 1852 , s. 112 i 127.

${ }^{29}$ R. K. Merton, op. cit., s. 78.

${ }^{30}$ F. Bacon, Novum organum, tłum. J. Wikarjak, Warszawa 1955, s. 85-89, 132 i 142-143; R. K. Merton, op. cit., s. 77.

${ }^{31}$ K. Mannheim, Człowiek i spoteczeństwo w dobie przebudowy, Warszawa 1974, s. 240-290; A. Loewe, Economics and Sociology, London 1935; M. Ginsberg, D. Litt, Sociology, Thornton Butter-Worth, London 1934. 
Czym więc sa, według Mertona, owe teorie średniego zasięgu i jakie maja cechy? Jeśli chodzi o pierwszą część pytania, to Merton wskazuje, że teoriami średniego zasięgu są teorie, „które znajdują się pomiędzy niezbyt doniosłymi, lecz koniecznymi hipotezami roboczymi powstającymi w nadmiarze w toku codziennej pracy badawczej i najogólniejszymi konsekwentnymi próbami rozwinięcia jednolitej teorii, dzięki której można byłoby wyjaśnić prawidłowości widoczne w zachowaniach organizacji oraz zmianie społecznej"32. Przy czym, co należy doprecyzować, wspomniana w przytoczonym cytacie „hipoteza robocza” - według Mertona, który powołuje się na Jamesa B. Conananta - „jest czymśs więcej niż zdroworozsądkowymi procedurami, jakimi się posługujemy w codziennej pracy. Kiedy się stykamy z pewnymi zjawiskami, przychodzą nam do głowy pewne alternatywne wytłumaczenia i staramy się je sprawdzić" 33 .

U Mertona znajdujemy też odpowiedź na drugą część postawionego przez autorkę pytania, mianowicie, czym cechuja się opisywane przez niego teorie średniego zasięgu. Wskazuje on tu mianowicie na osiem ich głównych właściwości: po pierwsze - teorie średniego zasięgu „składają się z określonych zbiorów założeń, z których można logicznie wyprowadzić konkretne hipotezy potwierdzane następnie badaniami empirycznymi”. Po drugie„teorie te nie są odrębne, ale są konsolidowane w szerszą sieć teoretyczną. Po trzecie - teorie te „zbudowane sa na tyle wystarczajacym poziomie abstrakcji, aby w sposób wykraczający poza czysty opis lub empiryczne uogólnienie mogły się zmierzyć z różnymi sferami życia i struktury społecznej”, po czwarte dzięki teoriom średniego zasięgu „przełamuje się rozróżnienie problemów mikrospołecznych [...] i makrospołecznych”. Po piąte - o czym przypomina Merton, „całościowe systemy teorii socjologicznej - takie jak historyczny materializm Marksa, teoria systemów społecznych Parsonsa ${ }^{34}$, czy integralna socjologia Sorokina - stanowią ogólne orientacje teoretyczne, a nie rygorystyczne zwarte systemy, które w fizyce są podstawą poszukiwań "jednolitej teorii«" i dlatego - po szóste - „w rezultacie wiele teorii średniego zasięgu jest zgodnych z wieloma różnymi systemami myśli socjologicznej”. Po siódme - jak zauważa Merton - „teorie średniego zasięgu są na ogół bezpośrednimi kontynuacjami klasycznych sformułowań teoretycznych”, dlatego - po ósme - „nastawienie się na tworzenie teorii średniego zasięgu wymaga określenia stopnia niewiedzy". Nie zakłada się tu, że sprosta zadaniu polegającemu na zapewnieniu rozwiązań teoretycznych wszystkich pilnych problemów praktycznych dnia dzisiejszego, ale stara się skupić na tych problemach, które w świetle dostępnej wiedzy mogą być wyjaśnione" 35 .

${ }^{32}$ R. K. Merton, op. cit., s. 61.

${ }_{33}$ J. B. Conanant, On Understanding Science, New Haven 1974, s. 173; za R. K. Merton, op. cit., s. 61 .

${ }^{34}$ Należy zwrócić uwagę, że w publikacji Mertona wielokrotnie przywoływana jest sylwetka jego najważniejszego antagonisty naukowego - Parsonsa, który był zwolennikiem całościowego systemu teoretycznego w naukach społecznych.

35 R. K. Merton, op. cit., s. 88-89. 


\section{TEORIA ŚREDNIEGO ZASIĘGU W METODZIE TEORII UGRUNTOWANEJ GLASERA I STRAUSSA}

Zdaniem autorki, bardzo istotnym dla nauk społecznych faktem jest to, że teorie średniego zasięgu znalazły zastosowanie w znanym na całym świecie, zwartym systemie metod badawczych, jakim jest teoria ugruntowana ${ }^{36}$ Barneya Glasera i Anselma Straussa. W tym miejscu należy oczywiście przybliżyć, choćby w zarysie, istotę wspomnianej teorii ugruntowanej. Sami jej twórcy wskazuja, że najprościej można powiedzieć, że metodologia ta polega na budowaniu teorii (średniego zasięgu) na podstawie systematycznie zbieranych danych empirycznych ${ }^{37}$. Teoria jest tutaj, jak doprecyzowuje w swojej pracy Krzysztof T. Konecki, pochodna analiz danych empirycznych ${ }^{38}$.

Jak już z samej przytoczonej definicji wynika, postępowanie badawcze charakterystyczne dla teorii ugruntowanej różni się od tego, które znamy u Mertona. Główna różnica polega na tym, że - jak celnie zauważa Konecki - „propozycje teoretyczne nie są budowane metodą logicznie dedukcyjną w oparciu o wcześniej przyjęte aksjomaty bądź założenia, jak ma to miejsce np. w teoriach Parson s a czy Merton a. Teoria wyłania się tutaj, w trakcie systematycznie prowadzonych badań, z danych empirycznych, które bezpośrednio odnoszą się do obserwowanej części rzeczywistości społecznej. Hipotezy, pojęcia i własności pojęć sa budowane w trakcie badań empirycznych i, także, podczas badań są one modyfikowane i weryfikowane. Tak więc budowanie teorii jest ściśle zwiazane z samym długotrwałym procesem badawczym" 39 . Dodatkowo warto podkreślić, że twórcy metody - Glaser i Strauss nie czynią żadnych ograniczeń w zakresie typów dobieranych danych. W swojej publikacji ${ }^{40}$ poświęcaja oni niemal tyle samo (albo i więcej) miejsca zarówno badaniom dokumentarnym, jak i terenowym. Nie dyskredytują również ani badań ilościowych, ani też jakościowych, o czym we wstępie polskiego przekładu ich pracy wspomina Konecki ${ }^{41}$, pisząc, że: „Glaser i Strauss traktują dane jakościowe i ilościowe jako równoprawne i równorzędnie nadające się do analizy teoretycznej”.

Konsekwencja przyjętego sposobu postępowania (polegajacego na odrzuceniu podejścia, w którym propozycje teoretyczne są budowane metodą logicznie dedukcyjną w oparciu o wcześniej przyjęte aksjomaty bądź założenia) jest to, że w teorii ugruntowanej postępuje się inaczej niż u Mertona, według którego teoria spekulatywna jest istotna i dopasowana do danych, dopóki nie zostanie obalona. Zdaniem twórców metody teorii ugrunto-

\footnotetext{
${ }^{36}$ Autorka będzie używać do oznaczenia zwartego systemu metod badawczych, jakim jest teoria ugruntowana, stosowanego najczęściej w literaturze skrótowego określenia „teoria ugruntowana” lub „metoda teorii ugruntowanej”.

${ }^{37}$ B. Glaser, A. Strauss, Discovery of Grounded Theory: Strategies for Qualitative Research, Chicago 1967, s. 1-2; B. Glaser, Theoretical Sensitivity, Mill Valley 1978, s. 2.

${ }^{38}$ K. T. Konecki, Studia z metodologii badań jakościowych. Teoria ugruntowana, Warszawa 2000, s. 26.

${ }^{39}$ Ibidem.

${ }^{40}$ B. Glaser, A. Strauss, Odkrywanie teorii ugruntowanej. Strategie badania jakościowego, Kraków 2009.

${ }^{41}$ Ibidem, s. XII.
} 
wanej to „dane powinny [...] pasować do teorii, a nie teoria do danych”42. Glaser i Strauss starają się zatem „budować teorię od podstaw, to znaczy, zaczynając od skonstruowania kategorii i ich własności na podstawie analizy wcześniej zebranych danych empirycznych. Teoria wyłania się zatem w ścisłym związku z badaniami empirycznymi, czy to o charakterze jakościowym, czy ilościowym”43. Zatem w teorii ugruntowanej dane stanowi „wszystko co się da”, i należy się w nich jedynie zanurzyć, dać im ponieść, a kategorie i własności same wyjda, by w ostatecznym efekcie przekształcić się, po odpowiednim nasyceniu teoretycznym (którego nie należy mylić z nasyceniem statystycznym) - w teorię (oczywiście średniego zasięgu). Przy czym teoria ta powinna być „ugruntowana w danych”, „bogata” i gęsta”. Takie podejście oznacza nic innego, jak odwrócenie tradycyjnie rozumianego procesu b a d a nia, w którym stawia się apriorycznie hipotezy, by następnie szukać za wszelką cenę danych, które mają je zweryfikować (a tak naprawdę często udowodnić po myśli autora badań). W metodzie teorii ugruntowanej taka sytuacja jest niemożliwa, ponieważ mamy w niej do czynienia z „cofnięciem się o krok” - z nacisku na weryfikowanie teorii na samo jej tworzenie.

Po przybliżeniu samej specyfiki metody teorii ugruntowanej, która przekłada się na to, ja k dochodzi się z jej użyciem do teorii średniego zasięgu, przyszedł czas na wyjaśnienie, c z y m dokładnie dla jej twórców są owe wypracowane teorie. Niewątpliwie udowodnione zostało, że są one postrzegane jako teorie średniego zasięgu, przy czym - jak wyjaśniają Glaser i Strauss - rozumieć przez to należy, iż „lokują się pomiędzy pomniejszymi »hipotezami roboczymi« codziennego życia a "obejmującymi wszystko« wielkimi teoriami" ${ }^{44}$.

W literaturze ciekawie tę kwestię rozwinęła i doprecyzowała Kathy Charmaz, krytykujac najpierw, że twórcy metody teorii ugruntowanej przyporządkowuja ją co prawda do teorii „średniego zasięgu" ${ }^{45}$, ale czynią to, nie wyjaśniając jednak wystarczająco dokładnie tego terminu. Stwierdziła ona następnie, że wyjaśnienie takie nie jest wcale prostą sprawa, ponieważ „brak jest dla tej metody jednoznacznej definicji teorï”46. Dalej zaś Charmaz przyznała, że różni „[...] autorzy różnie rozumieją ukończoną teorię ugruntowana" ${ }^{47}$. Można więc w piśmiennictwie natrafić na bardzo zróżnicowane poglądy definiujące efekt finalny stosowania metody teorii ugruntowanej (przy czym uwaga - sa to tylko przykłady, a nie, bynajmniej, katalog zamknięty): a mianowicie: empiryczne uogólnienie, kategorię, skłonność, objaśnienie procesu, związek między zmiennymi, wyjaśnienie, rozumienie abstrakcyjne, opis, czy wreszcie - pojęcie teoretyczne, będące pochodną analiz empirycznych i zaliczane do teorii średniego zasięgu ${ }^{48}$.

42 B. Glaser, A. Strauss, Discovery of Grounded Theory..., s. 260-261.

${ }^{43}$ B. Glaser, A. Strauss, Odkrywanie teorii ugruntowanej, s. XII.

${ }^{44}$ Ibidem, s. 31.

45 B. Glaser, A. Strauss, Discovery of Grounded Theory..., s. 1-2; B. Glaser, op. cit., s. 2.

${ }^{46}$ K. Charmaz, Teoria ugruntowana, praktyczny przewodnik po analizie jakościowej, Warszawa 2009 , s. 162.

47 Ibidem, s. 172

${ }^{48}$ K. Charmaz, op. cit., s. 172; K. T. Konecki, op. cit., s. 26; B. Glaser, A. Strauss, Discovery of Grounded Theory..., s. 1-2; B. Glaser, op. cit., s. 2. 


\section{NOWE SPOJRZENIE NA, ,ŚREDNI ZASIĘG” DOKONANE PRZEZ LAUGHLINA - PIERWSZE BEZPOŚREDNIE ODNIESIENIE DO NAUKI RACHUNKOWOŚCI}

W artykule na temat teorii średniego zasięgu i adekwatności jej generowania w nauce rachunkowości nie sposób pominąc głośny, w kręgach naukowców zajmujących się nurtem krytycznym rachunkowości, artykuł Richarda Laughlina ${ }^{49}$.

W literaturze wspomina się, że źródłem zapatrywań Laughlina jest inspiracja poglądami niemieckiego filozofa i socjologa Jürgena Habermasa ${ }^{50}$ - przedstawiciela szkoły frankfurckiej51, współcześnie uważanego za najbardziej znanego przedstawiciela teorii krytycznej. Aby jednak zachować obiektywizm, należy zwrócić uwagę na to, że w niektórych publikacjach ocenia się, że wykładnia prac Habermasa dokonana przez Laughlina nie jest zbyt udana ${ }^{52}$.

Artykuł Laughlina, jakkolwiek oceniany, zawiera dwa główne - ważne dla autorki - przesłania. Pierwszym z nich jest to, że Laughlin wyraźnie zauważa istnienie, w zasadzie od 1970 r., „dwóch skrzydeł” w nauce rachunkowości. Mowa tu o typowym, tradycyjnym podejściu do postrzegania rachunkowości jako ekonomii, ale także o eksponowaniu jej behawioralnego (społecznego) „skrzydła”. Istotne dla niniejszego artykułu jest jednak jego drugie przesłanie mianowicie zwrócenie uwagi na konieczność stosowania czegoś, co Laughlin wprowadza pod nazwą middle-range thinking ${ }^{53}$.

Określenie takie przywodzi na myśl skojarzenia z teoriami „średniego zasięgu" proponowanymi przez Mertona i jego następców, będących alternatywa dla „wielkich teorii” (zwłaszcza takich jak te Parsonsa), skupiającymi się na bardziej skromnym "teoretyzowaniu pierwszej instancji” z nadzieja, że te „ograniczone odkrycia” doprowadzą w końcu do oczekiwanych „wielkich teorii”, ale stanie się to w sposób stopniowy, a nie rewolucyjny ${ }^{54}$. Laughlin, pisząc o swoim pomyśle na middle-range thinking, stwierdza, że obejmuje on znacznie więcej, niż to, co prezentował Merton, a mianowicie, że bierze on pod uwagę podejście nie tylko do teorii, ale również do metodologii i zmian, co prezentuje rysunek 1 .

${ }^{49}$ R. Laughlin, Empirical Research in Accounting: Alternative Approaches and a Case for “Middle-range” Thinking, „Accounting, Auditing \& Accountability Journal” 8, 1995, nr 1, s. 63-87.

50 J. Broadbent, Building on Foundations: Analysing and Developing the Work of Richard Laughlin, „Critical Perspectives on Accounting” 24, 2013, s. 173; G. Lehman, Critical Reflections on Laughlin's Middle Range Research Approach: Language not Mysterious?, „Critical Perspectives on Accounting" 24, 2013, s. 211.

${ }_{11}$ S. Gallhofer, J. Haslam, A. Yonekura, Further Critical Reflections on a Contribution to the Methodological Issues Debate in Accounting, „Critical Perspectives on Accounting” 24, 2013, s. 192 .

${ }^{52}$ W. F. Chua, Translating Social Theory - A Critical Commentary, „Critical Perspectives on Accounting" 24, 2013, s. 259.

${ }^{53}$ R. Laughlin, op. cit., s. 65.

54 Ibidem, s. 63 i 79. 


\section{Rysunek 1}

Istota trzech wymiarów występujących w middle-range thinking Laughlina

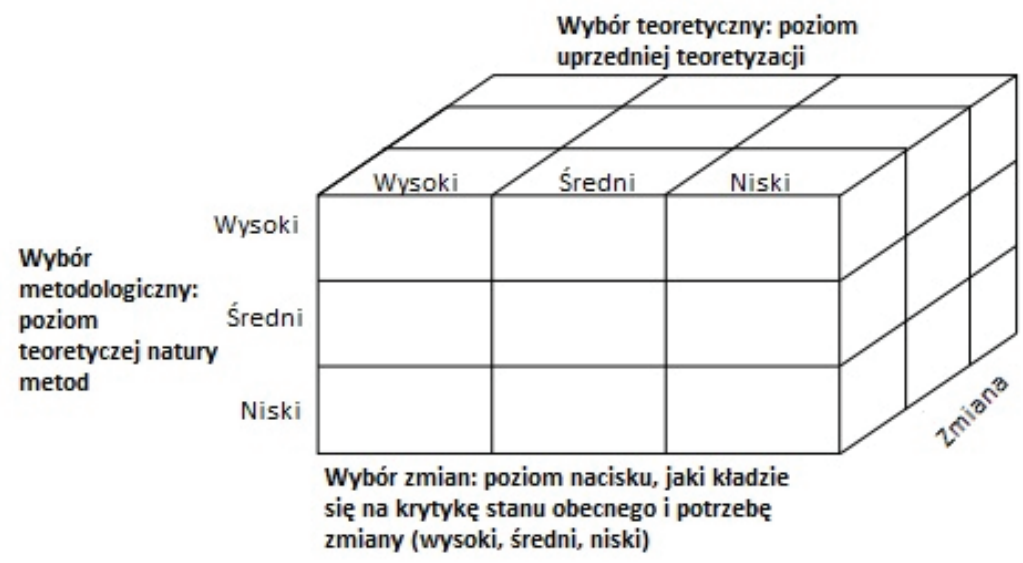

Źródło: opracowanie własne na podstawie artykułu Laughlina ${ }^{55}$.

Laughlin, odnosząc się do zaprezentowanego rysunku, wyjaśnia, że, jak to na nim wyraźnie wskazano, w odróżnieniu od Mertona, bierze on pod uwagę trzy wymiary:

- theory choice (przetłumaczony przez autorkę jako „wybór teoretyczny”), czyli poziom wykorzystania wcześniejszego teoretyzowania (istniejącego przed podjęciem badań),

- methodological choice (przetłumaczony niniejszym jako „wybór metodologiczny"), czyli poziom teoretycznego zamknięcia na metody badań,

- change choice (tu przetłumaczony jako „wybór zmian”) rozumiany jako poziom krytyki wobec status quo.

Przy czym, jak wskazuje Laughlin, każdy z trzech wyżej wymienionych wymiarów może osiagać niski, średni lub wysoki poziom. Jest zatem możliwych wiele kombinacji, ale co znamienne, Laughlin skupia się głównie na trzech z nich, występujących na przekatnej zaprezentowanego rysunku, a w dodatkowych opisach zaznacza, że kilka kombinacji z wyodrębnionych przez niego na rysunku pozostaje w ogóle niczym niezapełnionych.

Pierwsza, z wyszczególnionych przez Laughlina, jest sytuacja, gdy: wybór teorii (theory choice) ma poziom wysoki, wybór metodologii (methodological choice) - również poziom wysoki, a wybór zmiany (change choice) - poziom niski. Laughlin stwierdza, że w takiej sytuacji mamy do czynienia $\mathrm{z}$ archetypem modelu tych wszystkich przedsięwzięć naukowych, które bazują na założeniu, że materialny świat, który istnieje, jest odrębny od postrzegania użytkowników i czeka tylko na odkrycie. Wśród nich Laughlin wyróżnia: pozytywizm, realizm, instrumentalizm oraz konwencjonalizm.

\footnotetext{
${ }^{55}$ Ibidem, s. 80.
} 
Druga, skrajna sytuacja prezentowana na rysunku, to warunki, gdy wybór teorii (theory choice) ma poziom niski, wybór metodologii (methodological choice) - także poziom niski i wybór zmiany (change choice) - również niski. To z kolei przypadek, który jak wskazuje Laughlin, jest dokładnym przeciwieństwem pierwszego. Na tym drugim biegunie, jak stwierdza, znajdują się teorie, według których rzeczywistość odmienna od naszych ludzkich wyobrażeń i projekcji nie istnieje. Takie zapatrywania, według Laughlina, sa charakterystyczne dla pragmatyzmu, symbolicznego interakcjonizmu Blumera oraz etnometodologii.

Trzecim, wypośrodkowanym, zrównoważonym podejściem ma być sytuacja, gdy wybór zarówno teorii, metodologii, jak i zmiany osiagają średni poziom. Laughlin wspomina tu, że w takiej sytuacji, przy takim „średnim zasięgu” cechą charakterystyczna jest to, że szczegóły mają ogromne znaczenie, ponieważ uzupełniaja „szkielet” teorii, o czym szerzej pisze także Robert Gray ${ }^{56}$. Dodać należy, że ta najbardziej wypośrodkowana i pożądana, według Laughlina, sytuacja (średni/średni/średni poziom) ma miejsce tylko w przypadku niemieckiej teorii krytycznej ${ }^{57}$.

\section{WYKORZYSTANIE TEORII ŚREDNIEGO ZASIĘGU W NAUCE RACHUNKOWOŚCI}

Na wstępie należy zauważyć, że sama nauka rachunkowości, zwłaszcza od lat osiemdziesiatych XX w., staje się coraz bardziej behawioralna, społeczna, co skutkuje tym, iż obok tradycyjnych korzeni ekonomicznych ma coraz więcej cech, które charakterystyczne sa dla socjologii czy psychologii, na co liczne dowody znaleźć można w uznanej literaturze przedmiotu (przykładowo u Karmańskiej, Szychty, Hendriksena i van Bredy, Grabińskiego i wielu innych ${ }^{58}$ ), których poglądy na ten temat autorka zestawiła w innej publikacji ${ }^{59}$.

Logicznym następstwem stwierdzonego faktu, że rachunkowość ma (wspomniane choćby u cytowanego w niniejszym artykule Laughlina) „dwa skrzydła” (ekonomię i skrzydło behawioralne), jest to, że „badacze rachunkowości muszą uznać, że są naukowcami zajmującymi się nauką społeczna, by nie pozostawać $\mathrm{w}$ tyle za nowymi rozwiązaniami [...] oraz, że będą musieli poświęcić dużo uwagi naturze i praktyce tego, co jest uznane za dobre bada-

${ }^{56}$ R. Gray, Standing on the (Skeletal) Shoulders of a (Middle-range) Giant: Acknowledging Intellectual Debt, „Critical Perspectives on Accounting” 24, 2013, s. 207-210.

${ }^{57}$ R. Laughlin, op. cit., s. 81.

${ }^{58}$ A. Karmańska, Wielowymiarowość polityki rachunkowości i etyki z niq zwiazanej (artykut dyskusyjny), „Zeszyty Teoretyczne Rachunkowości” 56(112), Warszawa 2010; A. Szychta, Wspótczesne kierunki zainteresowania teorii rachunkowości finansowej w świetle zarysu jej rozwoju, „Zeszyty Teoretyczne Rachunkowości” 56(112), Warszawa 2010; E. S. Hendriksen, M. F. van Breda, Teoria rachunkowości, Warszawa 2002; K. Grabiński, Zarzadzanie zyskami jako jeden z kierunków rozwoju pozytywnej teorii rachunkowości, „Zeszyty Teoretyczne Rachunkowości” 56(112), Warszawa 2010.

${ }^{59}$ Zob. A. Piechocka-Kałużna, op. cit. 
nia w naukach społecznych"60, także w takich, jak wspomniana socjologia czy psychologia.

Cóż to oznacza dla nauki i teorii rachunkowości? Zdaniem autorki, jest to wystarczający powód, aby w pełnym zakresie rozpoczać stosowanie dla potrzeb prac naukowych z zakresu nauki rachunkowości, obok tradycyjnych metod (zarówno badawczych, jak i naukowych) charakterystycznych dla ekonomii, także tych, które będą adekwatne do specyfiki badań z zakresu jej „drugiego skrzydła”, czyli problemów badawczych występujących w jej aspektach behawioralnych. Oznacza to, że w kwestiach, którymi zajmuje się - nie wahajmy się użyć takiego sformułowania - „rachunkowość behawioralna”, można $\mathrm{z}$ powodzeniem stosować metody naukowe oraz metody i procedury badawcze, które sprawdzają się w takich naukach, jak socjologia czy psychologia. Konkludując, można więc stwierdzić, że zasadne jest prowadzenie badań w ramach behawioralnych aspektów występujących w rachunkowości, które zwieńczone będa, charakterystycznymi dla socjologii czy psychologii, teoriami średniego zasięgu.

Na tym etapie rozważań należałoby jeszcze omówić, który typ teorii średniego zasięgu (Mertona, Laughlina czy Straussa i Glasera) jest do behawioralnego skrzydła nauki rachunkowości najbardziej adekwatny.

Jeśli chodzi o klasyczną odmianę teorii średniego zasięgu, którą wypromował Merton, to jej zalety zostały już w niniejszym artykule odpowiednio dobitnie wyeksponowane. Dlatego w tym miejscu warto byłoby się skupić na jej wadach, po to, aby zarekomendować dla potrzeb nauki rachunkowości taka odmianę teorii średniego zasięgu, która pozwoli, w najszerszym możliwym zakresie, wyeliminować wszelkie ewentualne niedociagnięcia.

Mimo ogromnego wkładu w rozwój nauki, jakim było zwrócenie uwagi na konieczność konstruowania w naukach, głównie społecznych, teorii średniego zasięgu zamiast ogólnych systemów teoretycznych, należy zwrócić uwagę na pewne mankamenty podejścia stosowanego przez Mertona. Ich przykładem może być charakterystyczne podejście co do sposobu prowadzenia badań, a mianowicie rozpoczynanie prac badawczych od ciagłego „dialogu pomiędzy żywymi a martwymi”61. Merton wskazuje bowiem, że o ile „fizyk nie musi się pogrążać w lekturze Principiów Newtona, biolog nie musi czytać i ciagle wracać do $O$ powstaniu gatunków Darwina, to socjolog, i to wcale nie historyk socjologii, ma liczne powody do tego, ażeby studiować przed rozpoczęciem badań prace Webera, Durkheima, Simmla i wracać co pewien czas do pism Hobbesa, Rousseau Condorceta czy Saint-Simona" ${ }^{2}$.

Oczywiście autorka nie kwestionuje konieczności konfrontowania badań z wielkimi dziełami uczonych (klasyków) zajmujących się daną dziedzina i zgadza się z Mertonem, który pisze, że niektórzy „klasycy są tym, co Salvemini chętnie określał jako libri fecoundatori - książki które wyostrzają zdol-

${ }^{60}$ G. Morgan, Social Science and Accounting Research: A Commentary on Tomkins and Groves, „Accounting Organisation and Society” 8, 1983, s. 285.

${ }^{61}$ R. K. Merton, op. cit., s. 58.

62 Ibidem. 
ności wymagających czytelników poświęcających im niepodzielną uwage”, co jak żartobliwie wskazuje Merton - „naturalnie wymaga [...] intensywnego czytania klasyków: takiej koncentracji, jaką oczywiście miał ten prawdziwie oddany swej pracy uczony - opisany przez Edmunda Wilsona - który, kiedy przeszkodziło mu pukanie do drzwi, otworzył je i udusił przybysza, po czym wrócił do swej pracy”"63. Pułapką w takim podejściu może być jednak, zdaniem autorki, to, że rozpoczynanie pracy badawczej, czy szerzej: naukowej, od całkowitego zapatrzenia w mistrzów i naukowych mentorów może doprowadzić do dyskredytowania własnych odkryć lub nawet podświadomego nakierowywania ich na wytyczone przez wspomnianych klasyków szlaki.

Inną omówioną w niniejszym artykule propozycją z zakresu „średniego zasięgu" była ta, która została opisana w przytoczonym artykule Laughlina. Zawiera on dwa główne przesłania. Pierwszym z nich jest to, że Laughlin wyraźnie zauważa istnienie, w zasadzie od 1970 r., „dwóch skrzydeł” w nauce rachunkowości. Mowa tu o typowym, tradycyjnym podejściu do postrzegania rachunkowości jako ekonomii, ale także o eksponowaniu jej behawioralnego (społecznego) „skrzydła”64. Laughlin zauważa ${ }^{65}$, co pokrywa się ze spostrzeżeniami autorki zawartymi w innej publikacji ${ }^{66}$, że w $1970 \mathrm{r}$. rozpoczęto negację podejścia, że jedynym słusznym rozwiązaniem w zakresie efektów badań naukowych $\mathrm{w}$ rachunkowości jest stanowienie teorii normatywnych. Zapoczątkowano wtedy (ok. 1970) kierunek polegajaccy na stanowieniu teorii pozytywnych, który de facto w różnych mutacjach (najważniejsza z nich to od lat osiemdziesiąych XX w. zwrot w kierunku eksponowania w prowadzonych badaniach i w generowanych na ich podstawie teoriach pozytywnych aspektów b eh a wi o ralny ch) trwa do dziś. Laughlin docenia konieczność prowadzenia badań naukowych w taki sposób, aby jak najlepiej zagłębić się w występujące w nauce rachunkowości aspekty behawioralne i je zrozumieć. Roztropne jest jednak, że zwraca on także uwagę na istnienie drugiego, a w zasadzie (chronologicznie) „pierwszego skrzydła”, czyli konieczności pamiętania o umiejscowieniu rachunkowości w ekonomii (zdaniem autorki rozumianej jako dziedzina, a niekoniecznie dyscyplina). I za to chwała Laughlinowi.

Bardziej dyskusyjny jest za to drugi poruszany przez niego wątek - istotniejszy dla niniejszego artykułu - mianowicie, kwestia middle-range thinking, którą ma ilustrować przytoczony przez autorkę rysunek 1.

Niestety należy się na tym etapie rozważań poważnie zastanawiać, co tak naprawdę wnosi ten rysunek (wraz z interpretacja Laughlina), poza umiejscowieniem niemieckiej teorii krytycznej w ,jedynie słusznym punkcie”, o którym wspominaja choćby Sonja Gallhofer, Jim Haslam i Akira Yonekura, pisząc, że „uzasadnione jest stwierdzenie, że (artykuł Laughlina) to promowanie niemieckiej krytycznej orientacji teoretycznej” ${ }^{67}$.

\footnotetext{
${ }^{63}$ Ibidem, s. 59.

${ }^{64}$ R. Laughlin, op. cit., s. 63.

65 Ibidem.

66 A. Piechocka-Kałużna, op. cit.

67 S. Gallhofer, J. Haslam, A. Yonekura, op. cit., s. 192.
} 
Nie sposób także podczas analizy dołączonego do rysunku opisu Laughlina nie zwrócić uwagi na akceptację występowania pustych niewypełnionych kratek tego schematu, czekających na zwerbalizowanie charakterystycznych dla ich parametrów orientacji teoretycznych. Sam Laughlin stwierdza przecież, że „są takie możliwości teoretyczne, ale obecnie (kratki) nie wydają się zajęte" 68 . Nasuwa się tu pytanie, czy to taka genialna predykcja jak w przypadku tablicy Mendelejewa, na której uwzględnione były, wraz z cechami je charakteryzującymi, pierwiastki, które jak twierdził jej autor, istnieja, ale o których jeszcze nie wiemy, że występuja, czy też raczej w tym przypadku należy wprost mówić o braku spójności i niedopracowaniu proponowanego podejścia.

Jakkolwiek by oceniać pracę Lauglina, jedno jest pewne: jak wynika z powyższego, poza nazwą i przywołaniem osoby Mertona, middle-range thinking Laughlina ma niewiele wspólnego z tradycyjnie rozumianymi Mertonowskimi teoriami średniego zasięgu, co potwierdzają choćby wspomniani Gallhofer, Haslam i Yonekura ${ }^{69}$. Nawet sam Laughlin stwierdza, że jego „myślenie średniego zakresu” znacznie różni się od „średniego zasięgu” Mertona i „nie powinno być z nim mylone"70.

W podsumowaniu rozważań na temat propozycji Laughlina należy potwierdzić, że wskazanie przez niego konieczności zachowania równowagi między obydwoma występującymi w nauce rachunkowości skrzydłami, w znaczeniu dostrzegania, z jednej strony, jej aspektów ekonomicznych, ale także z drugiej strony (za Habermasem) aspektów behawioralnych (społecznych), jest niewątpliwie spostrzeżeniem rozsądnym. Samo jednak przedstawienie graficzne trzech wymiarów, które składaja się na middle-range thinking, z opisanych powyżej powodów może budzić i budzi nie tylko u autorki, ale także w literaturze uzasadnione zastrzeżenia.

Ostatnia opisana przez autorkę „odmiana” „teorii średniego zasięgu” to ta, która powstaje jako efekt finalny zwartego systemu metod badawczych zaproponowanego przez Glasera i Straussa, nazwanego przez nich teoria ugruntow ana. Teoria średniego zasięgu generowana w tym przypadku ma niewatpliwie wszystkie zalety tej proponowanej przez Mertona, ale - co ważne - wolna jest od wad występujących w wytycznych Mertona co do sposobu jej wypracowania. Przede wszystkim ze względu na specyfikę metody teorii ugruntowanej należy zauważyć, że nie generuje ona teorii na podstawie badań polegających na „patrzeniu ślepo w przeszłość”. Wręcz przeciwnie, postępowanie badacza jest, przynajmniej w początkowych fazach badań, całkowicie oderwane od przeszłości i tego, co teoria ugruntowana nazywa rama teoretyczna.

Dlatego bez wahania można stwierdzić, że zwarty system metod badawczych, zwany w skrócie teorią ugruntowana, to świeży, nowatorski powiew postępowania badawczego, w którym nie ma miejsca na „ciagłe rozmowy ze zmarłymi”. Dzieje się tak dlatego, że w metodzie teorii ugruntowanej

\footnotetext{
68 R. Laughlin, op. cit.

69 S. Gallhofer, J. Haslam, A. Yonekura, op. cit., s. 197.

70 R. Laughlin, op. cit., s. 79.
} 
ze względu na jej opisaną specyfikę celowo unika się na początku prac badawczych konfrontacji powstającej teorii z sądami uznanych autorytetów. Taka konfrontacja ma oczywiście miejsce, ale jest dokonywana dopiero po zakon c zeniu badań, podczas tzw. konfrontacji z ramą teoretyczna.

Podobnie jak w przypadku porównania teorii średniego zasięgu generowanej przez metodę teorii ugruntowanej z klasyczną teoria średniego zasięgu Mertona, tak samo i w przypadku jej konfrontacji z tym, co zaproponował Laughlin, wszelkie atuty są zdecydowanie po stronie tej pierwszej. Ściślej mówiąc, należy podkreślić, że to co było atutem podejścia Laughlina, czyli możliwość uchwycenia wszelkich społecznych, behawioralnych, a więc zarówno socjologicznych, jak i psychologicznych aspektów rachunkowości (jej behawioralnego skrzydła), występuje również w metodzie Glasera i Straussa, ale $\mathrm{u}$ tych ostatnich nie dokonano, zauważalnego u Laughlina, wypaczenia zalet idei Mertona.

Zwarty system metod badawczych wprowadzony przez Glasera i Straussa ma też inne niewątpliwe, przemawiające na jego korzyść zalety ${ }^{71}$. Wśród nich wymienić należy choćby dokładność, kompleksowość oraz elastyczność metody. Ważne jest też to, że jest ona niezwykle uniwersalna (stosowano ja z powodzeniem niemal we wszystkich typach nauk, w których znaczenie miał wątek behawioralny). Niewatpliwą zaletą metody teorii ugruntow a nej jest także proponowany w niej sposób (proces) prowadzenia badania (zanurzenie się $\mathrm{w}$ danych i notowanie spostrzeżeń, które same prowadzą do krystalizowania się najpierw kategorii, a później teorii średniego zasięgu). Istotne jest także wspomniane „odwrócenie tradycyjnie rozumianego procesu badania” oraz to, że to „dane pasują do teorii, a nie teoria pasuje do danych”. $\mathrm{W}$ metodzie teorii ugruntowanej $\mathrm{w}$ związku z powyższymi jej cechami nikt nie „doczepia fastrygą wyjaśnień wziętych z logicznie wydedukowanej teorii”. $\mathrm{Z}$ opisanych atutów teorii ugruntowanej wynika więc jednoznacznie, że otrzymana $\mathrm{w}$ efekcie postępowania badawczego zgodnego $\mathrm{z}$ jej metodami teoria „średniego zasięgu" gwarantuje rzetelny efekt finalny, ponieważ ze względu na specyfikę metody jest, jak to ujmują jej twórcy, solidnie „ugruntowana” w „bogatych” danych.

Reasumujac, dla teorii powstających w wyniku badań z „behawioralnego skrzydła” nauki rachunkowości „teorie średniego zasięgu”, a w szczególności te, które powstają w wyniku stosowania zwartego systemu metod badawczych nazywanych teoria ugruntow ana, sa jak najbardziej rozwiąaniem godnym zaufania. Dlatego też warto je, zdaniem autorki, zarekomendować szerszemu gronu naukowców zajmujacych się rachunkowością behawioralna.

\section{ZAKOŃCZENIE}

Jak wykazano w niniejszym artykule, dopiero uzmysłowienie sobie faktu, że nauki społeczne są inne od przyrodniczych, i tego, że nie można traktować poważnie monizmu naukowego, pozwoliło na dopuszczenie do głosu rozważań,

${ }^{71}$ Temat zalet metody teorii ugruntowanej i jej adekwatności dla nauki rachunkowości jest na tyle obszerny, że mógłby stanowić przedmiot odrębnej publikacji. 
które pozwalają generować inne typy teorii niż wszechobejmujące systemy teoretyczne charakterystyczne dla przyrodoznawstwa.

Wyjście z cienia fizykalizmu i preferowanych przezeń oraz przez różne szkoły filozoficzne całościowych systemów teoretycznych pozwoliło na zainteresowanie się możliwością stanowienia teorii średniego zasięgu. Choć kwestia teoretyzowania takiego typu kiełkowała od wielu wieków (niektórzy przypisują ją już nawet Platonowi), to należy uznać, że za twórcę klasycznej koncepcji tworzenia teorii średniego zasięu uważa się Mertona.

Idea Mertona była realizowana w niezmienionej formie przez wielu jego następców ${ }^{72}$. Dla nauki rachunkowości ważne są jednak, zdaniem autorki, obok klasycznego podejścia Mertona, także próby jego rozwinięcia, wykorzystania i modyfikowania dokonane przez Laughlina, a także Glasera i Straussa.

Praca Laughlina, przedstawiona i oceniona w artykule, uzmysłowiła, że wypaczenie klasycznej idei Mertona niekoniecznie przynosi pożądane efekty, ale przy okazji zwróciła także uwagę na kwestię o wiele ważniejsza, mianowicie, na konieczność dostrzegania „dwóch równoważnych skrzydeł” nauki rachunkowości - ekonomicznego i behawioralnego.

Wnioski ze zdiagnozowanych zalet oraz zidentyfikowanych słabości pracy Mertona i Laughlina pozwoliły na docenienie ogromnej adekwatności zwartego systemu metod badawczych - teorii ugruntowanej - do potrzeb teoretyzowania w nauce rachunkowości. Jak wykazano, teoria ugruntow a n a łaczy wszystkie zalety pomysłów Mertona i Laughlina, eliminujacc wady występujące w obu ujęciach. Teoria średniego zasięgu będąca zwieńczeniem prac prowadzonych zgodnie z metodyka teorii ugruntowanej jest bowiem, ze względu na specyfikę metody, solidnie „ugruntowana” w danych, nieporównywalnie „bogata” i ,gęsta”.

dr Agnieszka Piechocka-Katużna

Uniwersytet Ekonomiczny w Poznaniu

agnieszka.piechocka@ue.poznan.pl

ADEQUACY OF CONSTITUTION OF A MIDDLE-RANGE THEORY IN ACCOUNTING

Summary

In this article the authoress first describes the origin and the essence of the middle-range theory. Then, alongside the classical understanding of such type of theory presented by its creator (R. K. Merton) and his successors, she describes its two crucial modifications: one developed by Laughlin, and one adapted to the grounded theory of Glaser and Strauss. Finally, on the example of accounting, she explains how such theory may be implemented in social sciences.

${ }^{72}$ Por. F. H. Hankin, A Forty-Year Perspective, „Sociology and Social Research” 40, 1956, s. 398; A. K. Davis, Social Theory and Social Problems, „Philosophy and Phenomenological Research” 18, December 1975, s. 194; D. Riesmam, Some Observation on the „Older” and the „Newer” Social Sciences, w: L. D. White (red.), The State and the Social Sciences, Chicago 1956, s. 339. 
Copyright of Journal of Law, Economics and Sociology is the property of Faculty of Law and Administration of Adam Mickiewicz University in Poznan and its content may not be copied or emailed to multiple sites or posted to a listserv without the copyright holder's express written permission. However, users may print, download, or email articles for individual use.

Właścicielem praw autorskich do „Ruchu Prawniczego, Ekonomicznego i Socjologicznego” jest Wydział Prawa i Administracji Uniwersytetu im. Adama Mickiewicza w Poznaniu. Zawartość czasopisma nie może być kopiowana, przesyłana do innych stron internetowych bądź zamieszczana na blogach bez pisemnej zgody wydawcy. Niemniej artykuły można drukować, kopiować lub przesyłać w formie elektronicznej na własny użytek. 